\title{
Prehistoric earthquakes along the Shanchiao fault, Taipei Basin, northern Taiwan
}

\author{
Shao-Yi Huang ${ }^{\mathrm{a}, *}$, Charles M. Rubin ${ }^{\mathrm{b}, *}$, Yue-Gau Chen ${ }^{\mathrm{a}}$, Huan-Chi Liu ${ }^{\mathrm{c}}$ \\ ${ }^{a}$ Department of Geosciences, National Taiwan University, Taipei, Taiwan \\ ${ }^{\mathrm{b}}$ Department of Geological Sciences, Central Washington University, Washington, USA \\ ${ }^{\mathrm{c}}$ Central Geological Survey, Taipei, Taiwan
}

Received 24 February 2004; received in revised form 14 July 2005; accepted 27 July 2006

\begin{abstract}
Stratigraphic relations recorded in boreholes drilled along the Shanchiao fault, a normal fault that bounds the western margin of metropolitan Taipei, reveal evidence of early-mid Holocene subsidence and active extension of the Taipei Basin. Paleoseismic data suggest that the maximum displacement for each subsidence event ranges from 2.3 to $4.5 \mathrm{~m}$. Despite large uncertainties, the large offsets imply earthquake magnitudes that range in size from 6.9 to 7.1. Our results suggest that large magnitude earthquakes along the Shanchiao fault are one of the major seismic hazards in the metropolitan Taipei area.
\end{abstract}

(C) 2007 Elsevier Ltd. All rights reserved.

Keywords: Shanchiao fault; Normal fault; Taipei; Subsidence; Paleoearthquake

\section{Introduction}

The island of Taiwan is one of the most seismically active regions of the world. Numerous large magnitude earthquakes have produced surface ruptures in the last century, such as the $\mathrm{M}_{\mathrm{w}} 7.61999$ Chi-chi earthquake. This destructive earthquake has raised public awareness of seismic hazards in densely populated cities, in particular within the city of Taipei and surrounding metropolitan areas (Fig. 1).

With an unknown historic record of damaging earthquakes, the Shanchiao fault, a north-south trending normal fault, presents a poorly characterized earthquake hazard to Taipei. Similar to faults in other densely populated and urbanized basins, normal faults may pose greater hazards than much more distant plate boundary faults (McCalpin and Nishenko, 1996; Schwartz and Coppersmith, 1984). According to the archives on seismological activity of Central Weather Bureau, a magnitude 5.5

\footnotetext{
* Corresponding authors.

E-mail addresses: d94224003@ntu.edu.tw (S.-Y. Huang), charlier@ geology.cwu.edu (C.M. Rubin).
}

earthquake occurred in April 1694 and likely produced a marine intrusion into Taipei Basin, which is the only record that demonstrates recent co-seismic subsidence in the Taipei area. Efforts to characterize earthquake hazards in Taipei Basin are hampered by the absence of key data, such as fault slip rates and repeat times between earthquakes. This investigation along the Shanchiao fault is the first to constrain the timing of Holocene earthquakes along the fault.

Seismologic studies in Taiwan have traditionally focused on reverse and strike-slip faults because most of the island is located along a convergent boundary (Fig. 1) that absorbs nearly $85 \%$ of the total relative convergence of $82 \mathrm{~mm} / \mathrm{yr}$ between the Eurasian and Philippine Sea plates (Bos and Spakman, 2003; Yu et al., 1997). Recent geodetic studies indicate that the Taipei area is undergoing northwest-southeast extension at about $0.3-2.1 \mathrm{~mm} /$ yr (Yu et al., 1999a). This investigation of eight continuous borings across the Shanchiao fault is the first paleoseismic study in Taipei Basin to use sub-surface drill core data to provide long-term rates of earthquake occurrence (Fig. 2). 


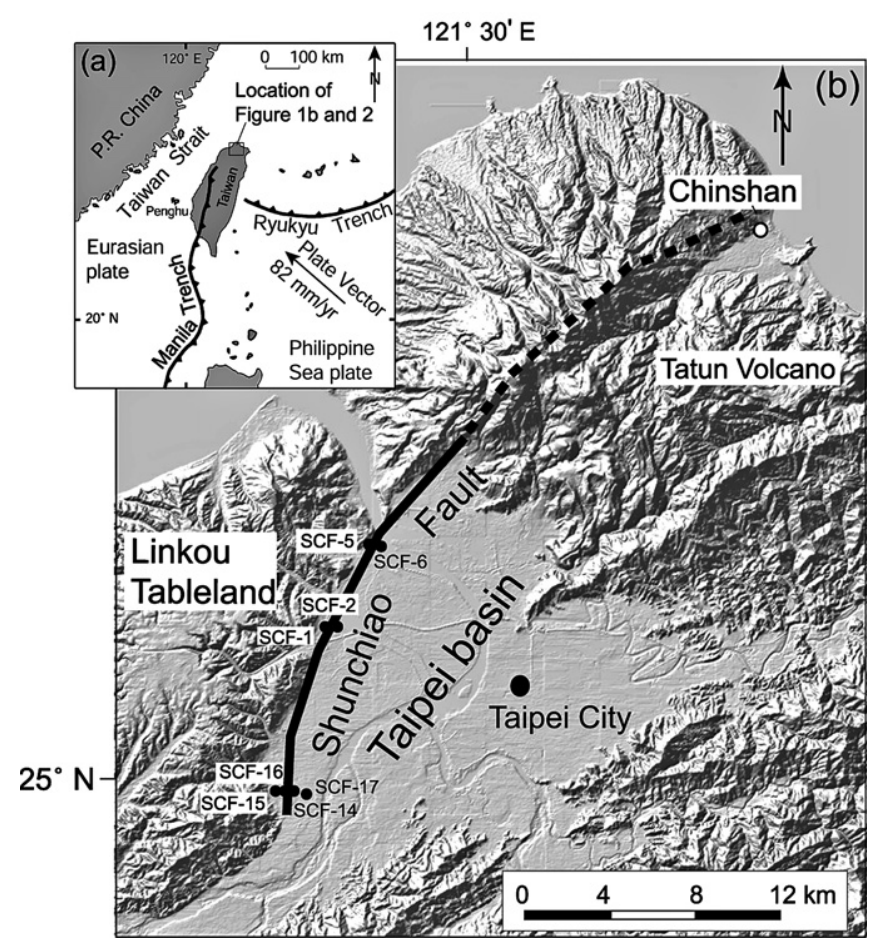

Fig. 1. (a) The tectonic setting of Taiwan. Extension across the Okinawa Trough produces extension in northern Taiwan. (b) Forty meter DEM of Taipei Basin showing the Shanchiao fault (bold black line) and the proposed northeastern extension (dashed black lines). Prominent lineation along the western flank of the Tatun Volcano extends toward offshore near Chinshan.

\subsection{Tectonic setting}

The island of Taiwan occupies the active plate boundary between the Eurasian and the Philippine Sea plates (Fig. 1). Complex plate boundary deformation results from two subduction zones of opposite polarity, the Ryukyu and Manila trenches. The ongoing collision between the Luzon volcanic arc and the Chinese continental margin, beginning in the late Miocene, has created the mountains of Taiwan (Ho, 1986; Teng, 1990). Because of the oblique orientation of the Luzon arc relative to the Chinese contine, shortening in Taiwan has migrated southward (Suppe, 1984; Yu et al., 1999b). To the north and east of Taiwan, the Philippine Sea plate is subducting beneath the Eurasian plate (Fig. 1a). The Ryukyu volcanic arc, extending from northeastern Taiwan to southwestern Japan, results from this subduction. Rollback of the Ryukyu volcanic arc and trench drives extension in the Eurasian plate, creating a back-arc along the Okinawa trough. Back-arc spreading extends westward into northeastern Taiwan, producing subsidence along the Shanchiao fault since $800 \mathrm{ka}$ (Teng et al., 2001).

Global Positioning System (GPS) measurements show that displacement vectors of the past decade are broadly consistent with simultaneous collision and extension (Bos and Spakman, 2003; Yu et al., 1997). Relative to Penghu Island in the foreland of the Taiwanese thrust belt
(Fig. 1a), the volcanic arc southeast of Taiwan and southeastern Taiwan are moving northwestward at rates of about $70 \mathrm{~mm} / \mathrm{yr}$. Rates of shortening decrease northward and are replaced by active extension across the northern one fifth of the island. Recent studies of the GPS velocity field indicate substantial NW-SE extension rates of about $2-16 \mathrm{~mm} / \mathrm{yr}$ in northern Taiwan (Yu et al., 1997). Extension is concentrated on the Shanchiao fault, a normal fault that bounds the western part of Taipei Basin.

\subsection{Geologic setting of Shanchiao fault zone}

Taipei Basin, located in the northern tip of Taiwan, is filled with Quaternary siliciclastic sediments that are at least $650 \mathrm{~m}$ thick in the middle of the depocenter (Fig. 2). To the east and south of the basin lie the frontal foothills of the Taiwan thrust and fold belt. North of the basin lies the Tatun volcanic area. The Linkou Tableland, located to the west of the basin, consists of alluvial gravel capped by a thick laterite soil (Lin, 1957). The surface of the tableland is fairly flat and the average elevation is approximately $220-250 \mathrm{~m}$ above sea level. The Shanchiao fault separates the Taipei Basin and the Linkou Tableland. The abrupt scarp between the high tableland and the low basin marks the surface expression of the Shanchiao fault (Fig. 2). Although the age of the Linkou Tableland surface is not well constrained, the surface is probably similar in age with the top of the Tertiary basement underlying Taipei Basin because the onset of basin sedimentation occurred right after the basement subsided below the adjacent tableland surface.

During the past few decades, several deep boreholes have provided data about the geometry of the basement, sub-surface faults, and Quaternary stratigraphy of Taipei Basin. The basin is a half-graben, subsiding mostly along its western margin. Quaternary strata in the basin thicken toward the west, implying continuous subsidence. The Quaternary strata in the basin have been divided into four stratigraphic packages, the Banchiao, Wugu, Jingmei, and Sungshan formations (Teng et al., 1999). The Banchiao and Wugu formations consist of interlayered sand, mud, and minor gravel, with minor, poorly sorted, angular volcaniclastic deposits. Based on their lithology, fossil assemblages, and stratigraphic relations, the strata were deposited in a fluvio-lacustrine setting.

The overlying Jingmei Formation consists of clast-supported gravel of late Pliocene age and is interpreted as an alluvial fan deposit. The Sungshan Formation is the uppermost strata in the basin and consists mainly of mud and thin sand layers. Abundant organic mud and mollusk shells indicate that the Sungshan Formation was deposited in an estuarine to semi-brackish lacustrine environment (Huang, 1962).

Based on thermoluminescence dating and palynology studies of the deepest sediments of the basin, the deposition of fluvial, estuarine, and lacustrine sediments began about 400,000 years ago (Liew et al., 1997; Wen and Peng, 1998; Wei et al., 1998). The deepest borehole in the basin, WK- 


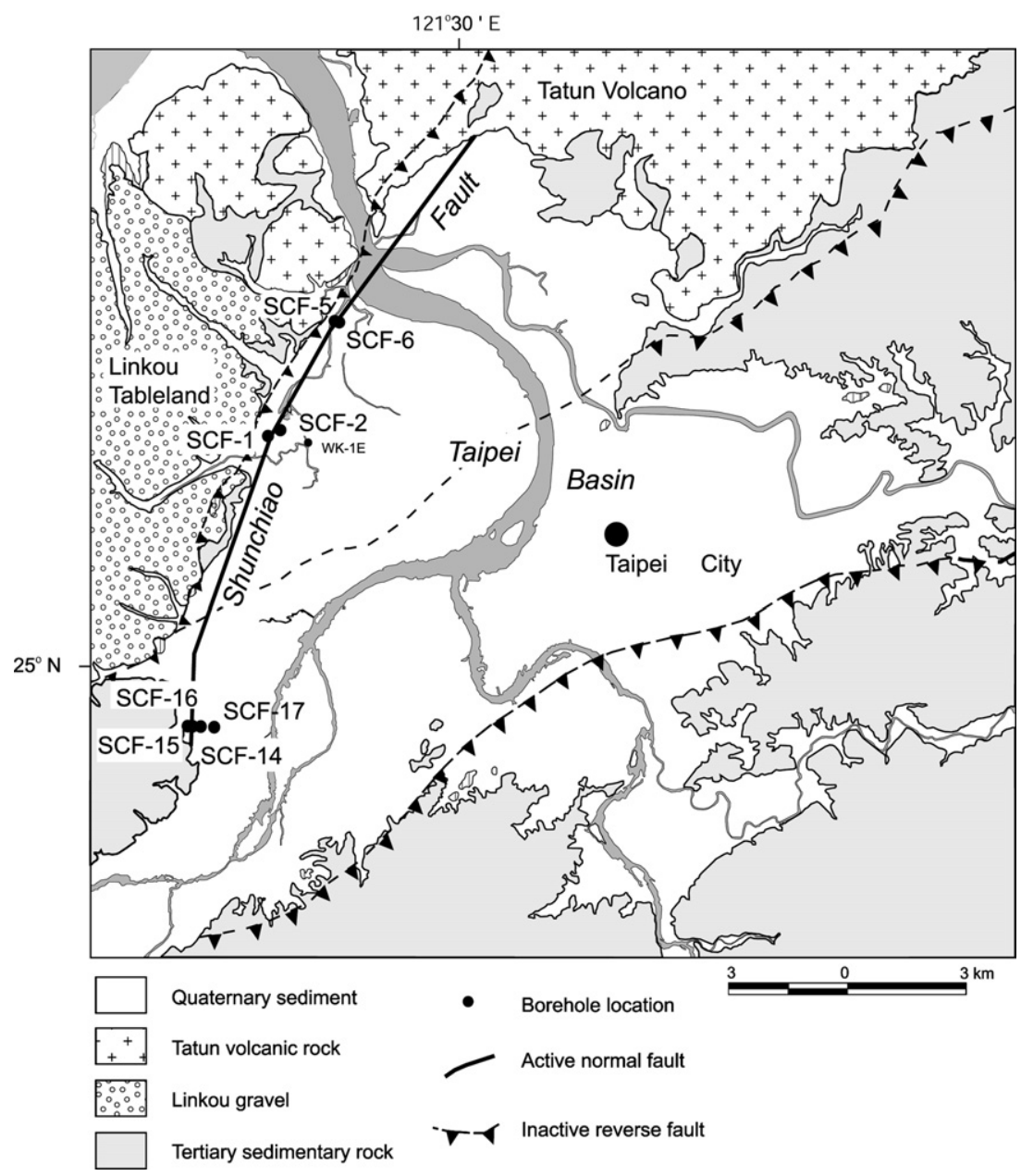

Fig. 2. Geologic map of the Taipei Basin showing location of drill holes.

$1 \mathrm{E}$, shows that the depth of the Tertiary basement is at least $679 \mathrm{~m}$ below the ground surface.

\section{Methods}

Our investigations include examining strata from eight boreholes and characterizing the lithology, fossil abundance, organic content, sedimentary structures and existence of paleosols. A continuous core of the Sungshan Formation consists of Holocene strata deposited in an estuarine to semibrackish lacustrine environment. Grain size and total carbon content analyses aided in borehole correlations. Peaty material, detrital charcoal, and mollusk shells, collected from the boreholes, provided material for radiocarbon dating of rates of Holocene subsidence in the basin.

Eight boreholes in the study are divided into three datasets: (1) boreholes SCF05 and SCF06 are located in the northern section of the Shanchiao fault; (2) boreholes SCF01 and SCF02 in the central part; and (3) boreholes SCF14, SCF15, SCF16, and SCF17 are located along the southern part of the fault (Fig. 2). Three correlation profiles were then established between each borehole pair based on lithology, fossil assemblages, and radiocarbon chronology.

\section{Borehole correlations}

\subsection{Correlation between boreholes SCF05 and SCFO6}

Boreholes SCF05 and SCF06 are located at the northern part of the fault, next to an manmade ditch (Fig. 2). Borehole SCF05 penetrates the Jingmei gravel bed at a depth of $62.1 \mathrm{~m}$ and Tertiary basement at $122.0 \mathrm{~m}$ (Fig. 3). Borehole SCF06 reaches the Jingmei gravel bed at a depth of $72.5 \mathrm{~m}$ and the top of Tertiary basement at $222.0 \mathrm{~m}$. Strata recovered from cores in boreholes SCF05 and SCF06 were divided into four units: (1) N1, mainly alluvial sand units; (2) N2, dominated by clay layers; (3) N3, sand units interbedded with clay layers; and (4) N4, mainly clayey units with a minor sandy layers. Previous studies by Chen and Liew (1990) suggest that the clayey horizons characterized by an abundance of pollen spores, especially in the early and middle Holocene, might reflect humid conditions during deposition. Similar variations in paleoclimate have also been documented in Japan and the vicinity of the South China Sea (Chen et al., 1999; Grossman et al., 2001). These climatic patterns in conjunction with lithology, occurrence of paleosols, and fossil assemblages helped us to establish the correlations. 


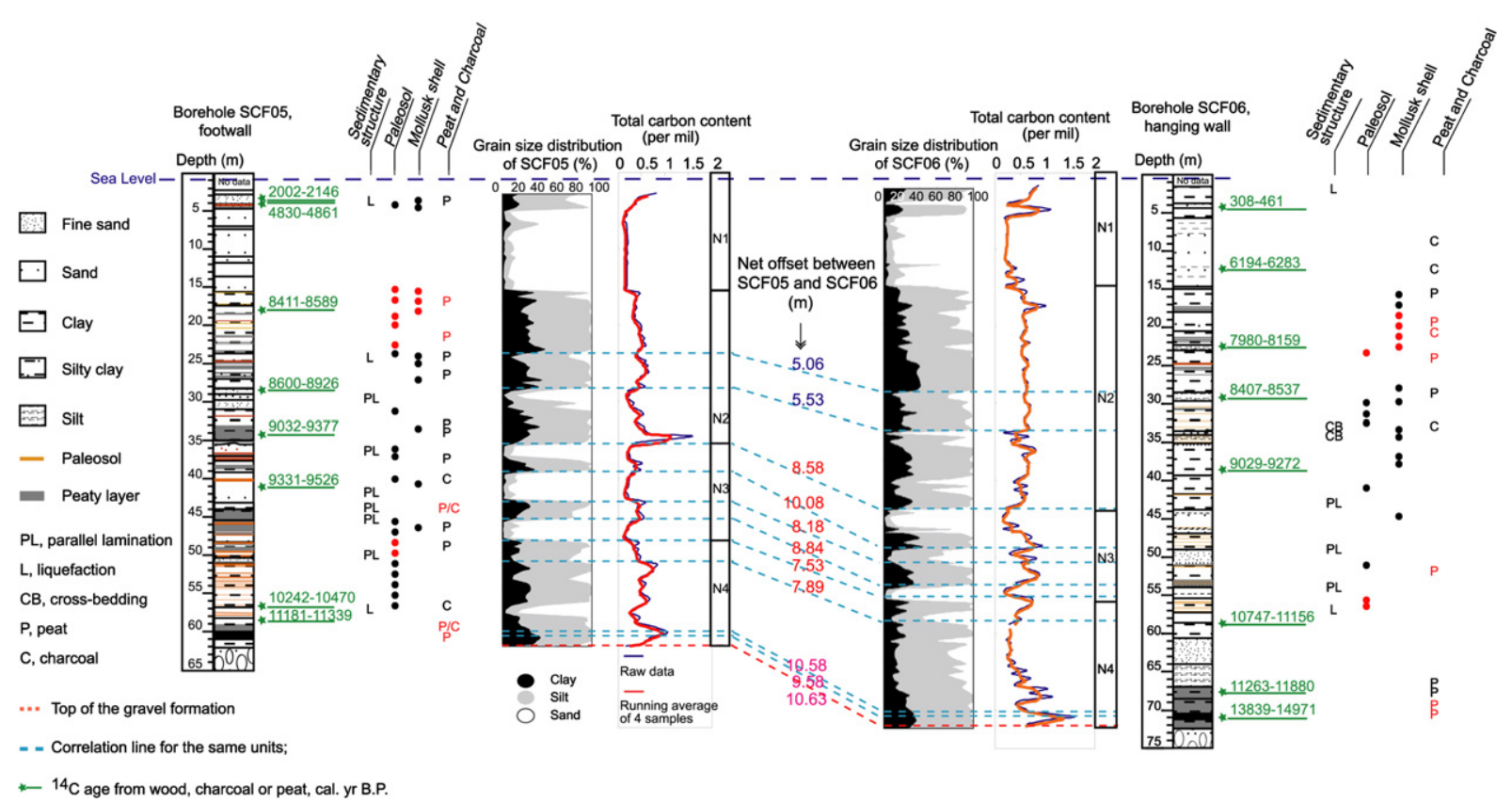

Fig. 3. The correlation profile of boreholes SCF05 and SCF06 with radiocarbon age controls. Grain size distribution is shown along with occurrence of paleosols, sedimentary structures, mollusk shell and charcoal or peat samples. Red text represents distinctive correlation features. The amount of net offset appears to be grouped into three sets, 5,8 , and $10 \mathrm{~m}$.

Table 1

Radiocarbon age of SCF14, SCF15, SCF16, and SCF17 from charcoal, wood and shell fragments

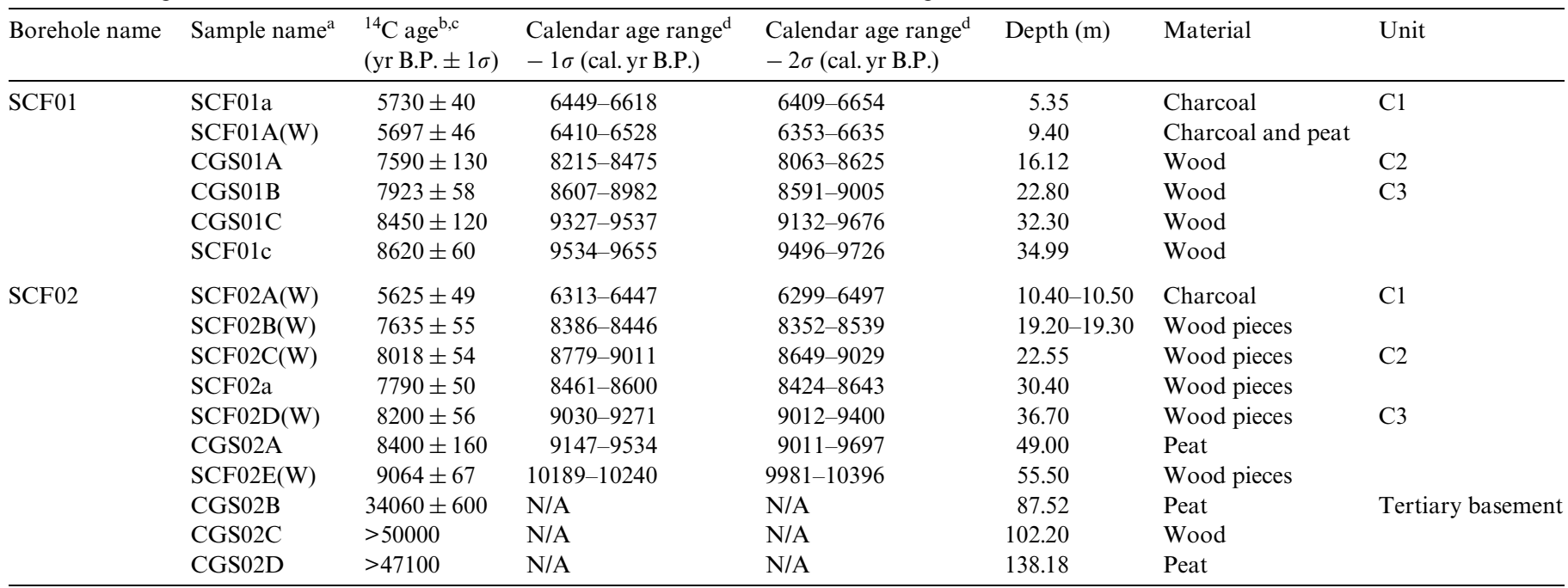

${ }^{a}$ Samples prepared and analyzed at Beta Analytic Laboratory and Wakaito Radiocarbon Dating Laboratory. Samples analyzed at Wakaito Radiocarbon Dating Laboratory are labeled with (w).

${ }^{\mathrm{b}} \delta^{13} \mathrm{C}$ value of $-25 \%$ are assumed according to Stuiver and Polach (1977).

c The quoted age in radiocarbon years used Libby half-life of 5568 years and followed the conversion of Stuiver and Polach (1977).

${ }^{\mathrm{d}}$ Calibration with CALIB4.3 (Stuiver and Reimer, 2002).

Twenty samples were processed for radiocarbon dating: nine from borehole SCF05 and eleven from SCF06 (Table 1). Most of the samples are detrital charcoal or wood fragments, four samples are mollusk shells, two from borehole SCF05 and two from borehole SCF06. All radiocarbon dates based on detrital charcoal are in stratigraphic order except sample CGS06C, which we interpret as reworked wood that gives an older age than the strata. Radiocarbon ages of mollusk shells are systematically older than woody samples due to the uncertainties in initial carbon value. We therefore excluded sample CGSO6C and the mollusk shell samples when compiling the chronostratigraphy.

Section N1 was deposited from about 7000 cal. yr B.P. to the present and consists mainly of alluvial sand with minor charcoal and mollusk shells. The total carbon content is generally low in this section. Section N2 was deposited from 9000 to $8000 \mathrm{cal}$ yr B.P. and suggests a hiatus of sedimentation between sections $\mathrm{N} 1$ and $\mathrm{N} 2$. 
Section N2 is composed of clay units and abundant mollusk shells. Paleosols and peaty layers are common in this section as well as mollusk shells (e.g., Placuna placenta). The presence of Placuna placenta and the clayey sedimentary texture indicate a semi-brackish lacustrine environment.

Section N3 was deposited at about 9000 cal.yr B.P. and consists of three major sand units and two clayey layers (Fig. 3). The sand units display parallel sedimentary lamination and well-rounded grain shape. Section N4 was deposited from 15,000 to 10,000 cal.yr B.P., and consists mainly of clayey units. Section N4 penetrates Jingmei gravel at the bottom of the borehole. A conspicuous peaty layer conformably overlies the contact between the Jingmei gravel and section N4. The conformability of the peaty layer suggests that the top of the Jingmei gravel unit in boreholes SCF05 and SCF06 are similar in age. Sedimentation between sections N4 and N2 appears to be continuous, suggesting a reliable correlation between the two boreholes. Based on the radiocarbon date of the peat, the sharp transition between the gravel and section N4 occurred at about 15,000 cal.yr B.P.

Stratigraphic correlations reveal a distinctive pattern of net offset between boreholes SCF05 and SCF06, increasing with depth (Fig. 3). The net offset between SCF05 and SCF06 changes abruptly from 5 to $8 \mathrm{~m}$ at 9000 to 9300 cal.yr B.P., implying rapid subsidence. The second abrupt offset of $2 \mathrm{~m}$ occurred at about $11,100 \mathrm{cal}$. yr B.P., suggesting an earlier, rapid subsidence event.

\subsection{Correlation between boreholes $S C F 01$ and $S C F 02$}

Boreholes SCF01 and SCF02 are located along the central part of the Shanchiao fault, the depocenter of the Tai- pei Basin. The present day depositional setting at boreholes SCF01 and SCF02 is relatively flat lowland to semi-brackish marshes. Borehole SCF01 reaches the Jingmei gravel at a depth of $35.2 \mathrm{~m}$ and encounters Tertiary sedimentary basement at the depth of $38.0 \mathrm{~m}$. SCF02 reaches Jingmei gravel at a depth of $59.9 \mathrm{~m}$. Stratigraphic units from boreholes SCF01 and SCF02 were divided into three sections: (1) C1, mainly alluvial sand units; (2) C2, chiefly clayey units; and (3) C3, alternating sand and clay layers (Fig. 4). Thirteen radiocarbon samples of detrital charcoal fragments, peat, and wood were analyzed from these two boreholes (Table 2). All the radiocarbon dates are in stratigraphic order except sample SCF02C(W), a woody fragment collected from borehole SCF02 at a depth of $22.6 \mathrm{~m}$. The radiocarbon age of 8779-9001 cal. yr B.P. from this sample is substantially older than the underlying strata, suggesting the woody fragment was reworked and, therefore, was not included in our calculation for the timing of subsidence.

Section C1 was deposited from 8400 cal.yr B.P. to the present and consists of alluvial sand units. Mollusk shells occur in the bottom of this section. Underlying section $\mathrm{C} 1$, section $\mathrm{C} 2$ was deposited at about 8000 cal. yr B.P. and consists mainly of clay units with abundant paleosols. This section has abundant detrital charcoal fragments and some mollusk shells. The stratigraphically lower section C3 displays alternating sand and clay units and reaches Jingmei gravel at the bottom. Charcoal and peaty materials are abundant in the clayey layers. The strata at the bottom of section $\mathrm{C} 3$ are not correlative between the two boreholes, suggesting that the tops of Jingmei gravel of boreholes SCF01 and SCF02 are probably not coeval. Section C3 was estimated to have been deposited from ca. 10,000 to

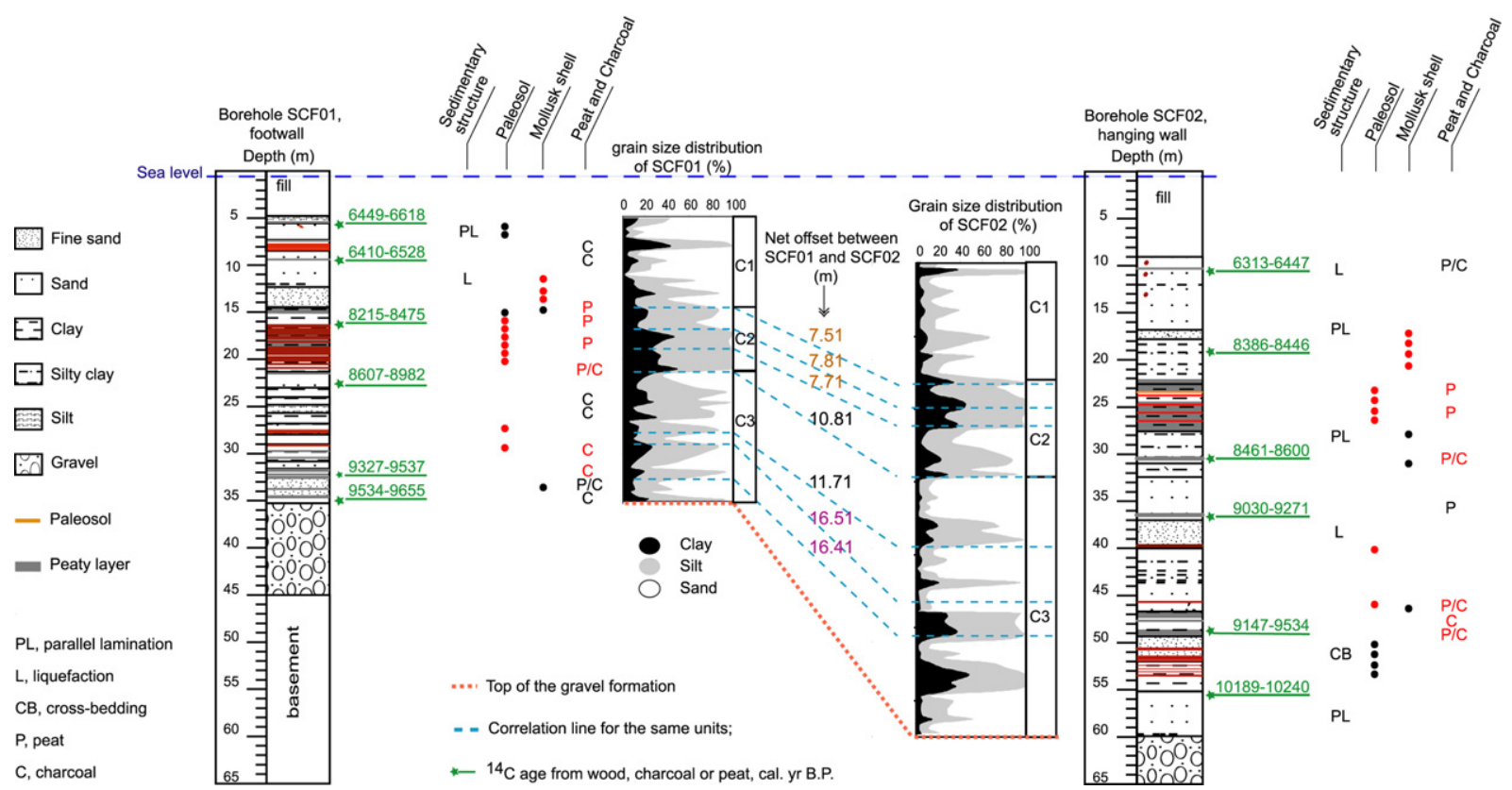

Fig. 4. The correlation profile of boreholes SCF01 and SCF02 with radiocarbon age controls. Grain size distribution is shown along with occurrence of paleosols, sedimentary structures, mollusk shell, and charcoal or peat samples. Red text represents distinctive correlation features. The amount of net offset appears to be grouped into three sets, 8,12 , and $16 \mathrm{~m}$. 
Table 2

Radiocarbon age of SCF01 and SCF02 from charcoal, wood, and shell fragments

\begin{tabular}{|c|c|c|c|c|c|c|c|}
\hline Borehole name & Sample name ${ }^{\mathrm{a}}$ & $\begin{array}{l}{ }^{14} \mathrm{Cage}^{\mathrm{b}, \mathrm{c}} \\
(\mathrm{yr} \text { B.P. } \pm 1 \sigma)\end{array}$ & $\begin{array}{l}\text { Calendar age range } \\
-1 \sigma \text { (cal. yr B.P.) }\end{array}$ & $\begin{array}{l}\text { Calendar age range } \\
-2 \sigma \text { (cal. yr B.P.) }\end{array}$ & Depth (m) & Material & Unit \\
\hline \multirow[t]{9}{*}{$\overline{\mathrm{SCF} 05}$} & SCF05a & $2110 \pm 40$ & $2002-2146$ & $1951-2297$ & 3.60 & Wood pieces & N1 \\
\hline & $\mathrm{SCF} 05 \mathrm{~b}$ & $4280 \pm 40$ & $4830-4861$ & $4743-4871$ & $3.90-3.95$ & Shell & \\
\hline & CGS05A & $7720 \pm 70$ & $8411-8589$ & $8386-8631$ & $18.10-18.12$ & Wood & $\mathrm{N} 2$ \\
\hline & CGS05B & $7940 \pm 130$ & $8592-9010$ & $8421-9243$ & $23.75-23.80$ & Shell & \\
\hline & $\mathrm{SCF} 05 \mathrm{c}$ & $7890 \pm 40$ & $8600-8926$ & $8590-8980$ & 28.40 & Wood pieces & \\
\hline & CGS05C & $8220 \pm 60$ & $9032-9397$ & $9014-9423$ & $34.37-34.40$ & Wood & \\
\hline & CGS05D & $8430 \pm 70$ & $9331-9526$ & $9165-9539$ & $41.19-41.20$ & Wood & N3 \\
\hline & SCF05d & $9200 \pm 40$ & $10242-10470$ & $10236-10496$ & 56.80 & Wood pieces & N4 \\
\hline & CGS05E & $9870 \pm 110$ & 11181-11339 & $11116-11687$ & $58.78-58.83$ & Wood & \\
\hline \multirow[t]{11}{*}{ SCF06 } & SCF06a & $320 \pm 40$ & $308-461$ & $294-486$ & 4.35 & Wood & N1 \\
\hline & $\mathrm{SCF} 06 \mathrm{~b}$ & $5420 \pm 40$ & $6194-6283$ & $6003-6293$ & 12.50 & Wood pieces & \\
\hline & CGS06A & $7640 \pm 60$ & $8386-8449$ & $8350-8541$ & $20.10-20.12$ & shell & $\mathrm{N} 2$ \\
\hline & $\mathrm{SCF} 06 \mathrm{~A}(\mathrm{~W})$ & $7263 \pm 51$ & $7980-8159$ & $7961-8177$ & 22.70 & Wood pieces & \\
\hline & $\mathrm{SCF} 06 \mathrm{~B}(\mathrm{~W})$ & $7682 \pm 52$ & $8407-8537$ & $8385-8589$ & 29.20 & Wood pieces & \\
\hline & CGS06B & $8350 \pm 60$ & $9279-9471$ & $9135-9518$ & $32.00-32.03$ & Shell & \\
\hline & $\mathrm{SCF} 06 \mathrm{C}(\mathrm{W})$ & $8195 \pm 63$ & $9029-9272$ & 9009-9401 & 38.70 & Wood pieces & \\
\hline & CGS06C & $8700 \pm 70$ & $9550-9886$ & $9533-10107$ & $40.40-40.45$ & Wood & \\
\hline & CGS06D & $9590 \pm 60$ & $10747-11156$ & $10691-11169$ & $58.89-58.90$ & Wood & N4 \\
\hline & CGS06E & $10040 \pm 70$ & $11263-11880$ & $11234-12102$ & $67.89-67.90$ & Wood & \\
\hline & $\mathrm{SCF} 06 \mathrm{D}(\mathrm{W})$ & $12044 \pm 79$ & 13839-14971 & $13663-15341$ & 71.00 & Peat and charcoal & \\
\hline
\end{tabular}

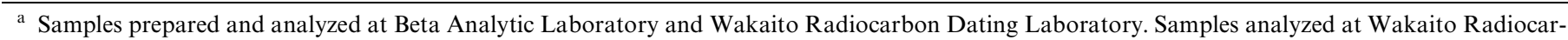
bon Dating Laboratory are labeled with (w).

b $\delta^{13} \mathrm{C}$ value of $-25 \%$ are assumed according to Stuiver and Polach (1977).

c The quoted age in radiocarbon years used Libby half-life of 5568 years and followed the conversion of Stuiver and Polach (1977).

d Calibration with CALIB4.3 (Stuiver and Reimer, 2002).

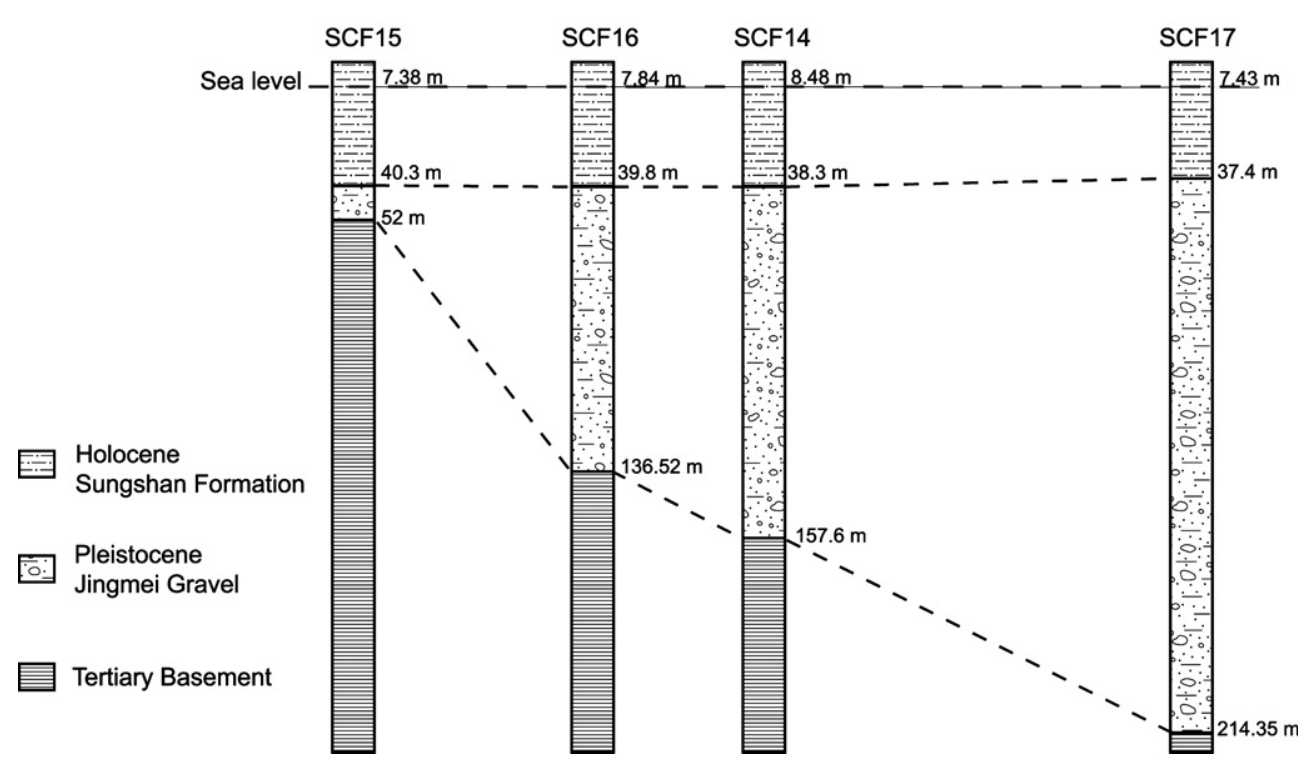

Fig. 5. The correlation profile of boreholes SCF15, SCF16, SCF14, and SCF17. Although the boreholes did not show displacement between Quaternary strata, at least $80 \mathrm{~m}$ offset between the Tertiary basement is apparent.

8000 cal. yr B.P. The contact between Jingmei gravel and section C3 should be older than 10,000 cal. yr B.P., due to the hiatus of sedimentation.

The correlation profile of boreholes SCF01 and SCF02 displays a pattern of thickening similar to that documented between boreholes SCF05 and SCF06 (Fig. 3). The net offset between boreholes SCF01 and SCF02 is $8 \mathrm{~m}$ for the period of early 8000 cal.yr B.P., then abruptly increases $11 \mathrm{~m}$ at 8400 to 8600 cal. yr B.P., suggesting rapid subsidence of $3.7 \mathrm{~m}$. At about 9100 to $9200 \mathrm{cal}$. yr B.P., the net offset changes from 11-12 to $16.8 \mathrm{~m}$, suggesting subsidence of about $4.5 \mathrm{~m}$. The amount of subsidence in boreholes SCF01 and SCF02 is greater than subsidence documented in the northern boreholes and can be interpreted to reflect a higher rate of deposition within the basin. 
Table 3

Radiocarbon age of SCF14, SCF15, SCF16, and SCF17 from charcoal, wood, and shell fragments

\begin{tabular}{|c|c|c|c|c|c|c|}
\hline Borehole name & Sample name ${ }^{\mathrm{a}}$ & $\begin{array}{l}{ }^{14} \mathrm{C} \text { age } \mathrm{ag}^{\mathrm{b}, \mathrm{c}} \\
(\mathrm{yr} \text { B.P. } \pm 1 \sigma)\end{array}$ & $\begin{array}{l}\text { Calendar age range } \\
-1 \sigma \text { (cal. yr B.P.) }\end{array}$ & $\begin{array}{l}\text { Calendar age range } \\
-2 \sigma \text { (cal. yr B.P.) }\end{array}$ & Depth (m) & Material \\
\hline SCF14 & SCF14A(W) & $8909 \pm 59$ & 9914-10185 & $9778-10212$ & 38.40 & Wood piece \\
\hline SCF15 & SCF15A(W) & $8199 \pm 56$ & $9030-9271$ & $9012-9400$ & 40.25 & Charcoal \\
\hline SCF16 & SCF16A(W) & $9338 \pm 60$ & $10429-10668$ & $10289-10730$ & $37.75-37.80$ & Peat and organic sediment \\
\hline SCF16 & scf16a & $9210 \pm 150$ & $10218-10577$ & 9924-11036 & 37.50 & Charcoal \\
\hline SCF17 & $\mathrm{SCF} 17 \mathrm{~A}(\mathrm{~W})$ & $9517 \pm 62$ & $10645-11068$ & $10580-11155$ & $37.25-37.30$ & Organic sediment \\
\hline SCF17 & $\operatorname{scf} 17 \mathrm{a}$ & $8130 \pm 280$ & $8603-9471$ & $8382-9675$ & 37.10 & Wood \\
\hline
\end{tabular}

a Samples prepared and analyzed at Beta Analytic Laboratory and Wakaito Radiocarbon Dating Laboratory. Samples analyzed at Wakaito Radiocarbon Dating Laboratory are labeled with (w).

b $\delta^{13} \mathrm{C}$ value of $-25 \%$ are assumed according to Stuiver and Polach (1977).

${ }^{c}$ The quoted age in radiocarbon years using Libby half-life of 5568 years and followed the conversion of Stuiver and Polach (1977).

${ }^{\mathrm{d}}$ Calibration with CALIB4.3 (Stuiver and Reimer, 2002).

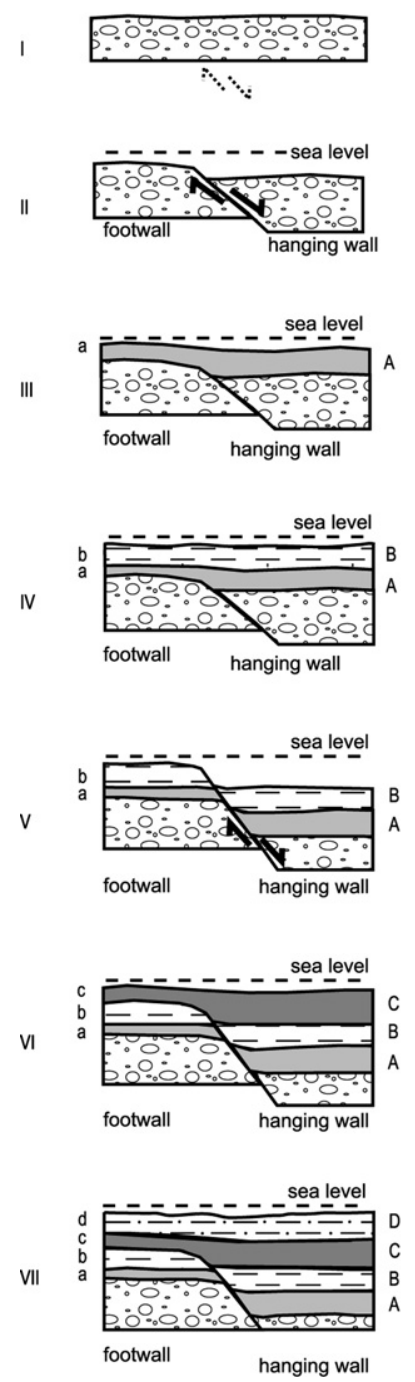

An original surface.

The normal fault lies beneath the alluvial gravel.

Normal faulting results in rapid subsidence of the hanging wall.

Sediments are deposited across the fault scarp and gradually aggrade up to another new surface.

Sedimentation continues. After faultrelated subsidence, the strata thickens across the hanging wall block.

\section{A later earthquake and rapid subsidence.}

Sedimentation continues and buries the surface trace of the fault and the surface.

\section{Sedimentation continues. \\ Thickness changes across strata A-a and $\mathrm{C}-\mathrm{c}$ record rapid fault-related subsidence. Section is now ready to record next normal fault earthquake.}

Fig. 6. Model of rapid subsidence along a normal fault.

\subsection{Correlation of boreholes SCF14, SCF15, SCF16, and SCF17}

Boreholes SCF15, SCF16, SCF14, and SCF17 (from west to east) are located along the southwestern corner of the Taipei Basin (Fig. 2). Boreholes are located at the mountain front, near the main channel of the Tahansi River. These four boreholes penetrate similar thickness of the Sungshan Formation of about $40 \mathrm{~m}$ (Fig. 5) and substantial separation between Tertiary basements of about $80 \mathrm{~m}$. Six radiocarbon samples of charcoal, peat, and wood were analyzed (Table 3). The separation of 


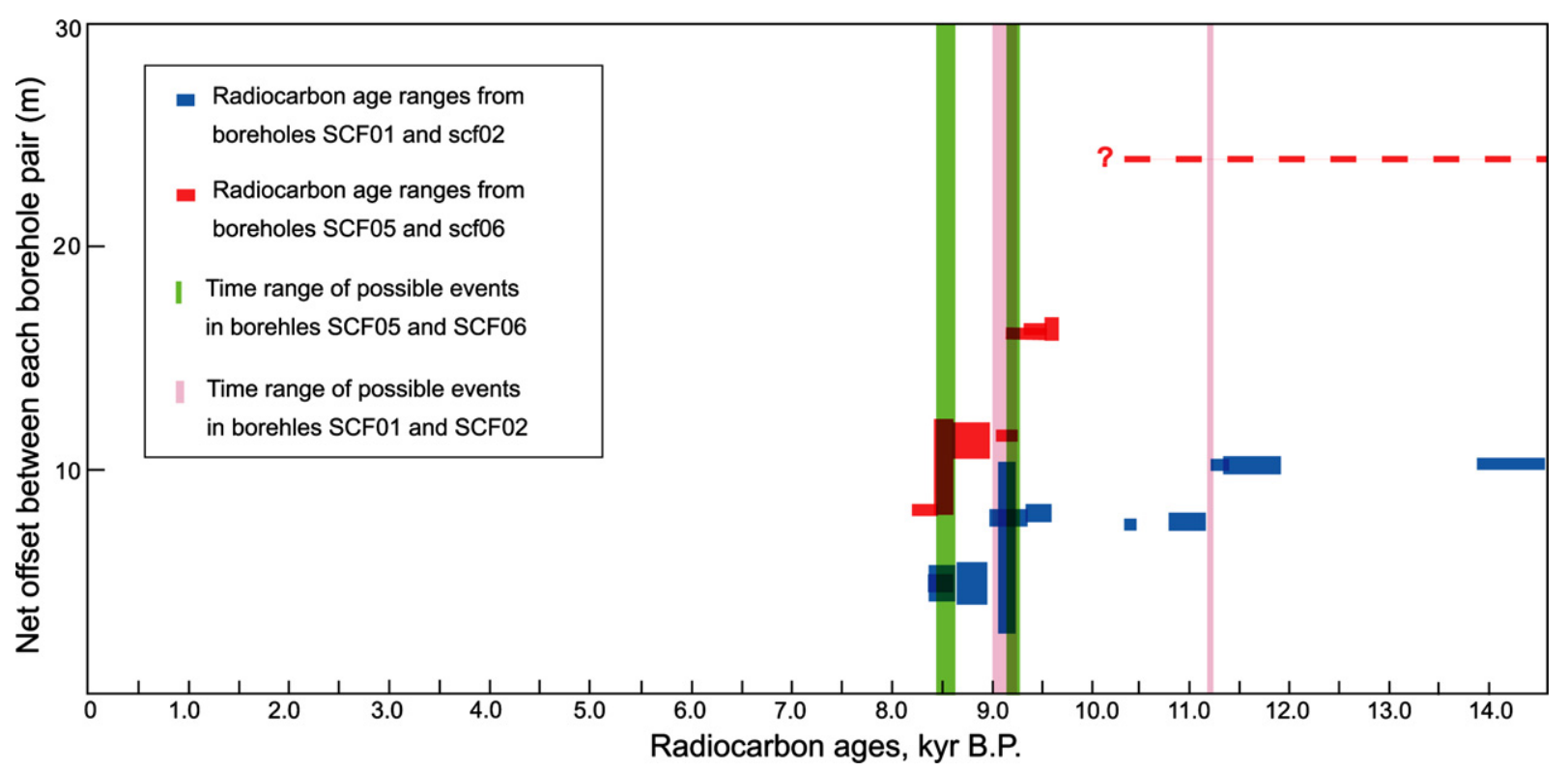

Fig. 7. Net offset and timing of two subsidence events recorded in boreholes SCF05, SCF06, SCF01, and SCF02. Horizontal axis represents radiocarbon ages acquired from each radiocarbon samples and vertical axis represents corresponding amount of net offset in layers where the dating materials were collected. Increase of net offset implies rapid subsidence events as marked pink at 9.0 and $11.2 \mathrm{kyr}$ B.P. in SCF01-SCF02 pair; green at 8.5 and 9.1 kyr B.P. in SCF05-SCF06 pair.

Tertiary basement can be interpreted to reflect a history of subsidence prior to the Holocene. However, the location of these boreholes lies very close to the tributary from adjacent hills and the main channel of the Tahansi River, which raises the possibility that lateral thickness changes in gravels could be depositional and merely record local fluvial deposition.

\section{Discussion}

\subsection{Conceptual model of sedimentation across a normal fault}

Differences in stratigraphic relations across normal faults provide evidence for prehistoric earthquakes that displace unconsolidated materials. For example, in a lacustrine setting, the hanging wall block accumulates sediment at a faster rate than the footwall block (Fig. 6). If the slip rate is less than the role of deposition, a new surface will gradually aggrade across the fault scarp. Multiple faulting events will preserve thicker strata in the hanging wall block than corresponding strata in the footwall block. Substantial changes in stratigraphic thickness across the fault scarp thus record past earthquakes. Two critical assumptions are required in this model: (1) the boreholes cannot be located too far apart from each other in order to confidently correlate strata across lateral facies variation; (2) the sedimentation must be continuous. In this study, the distance between correlated boreholes is less than $100 \mathrm{~m}$ and the difference of elevation between each borehole is less than $0.3 \mathrm{~m}$, which is sufficient for our analysis. In addition, since the Sungshan Formation was continuously deposited in an estuarine to semi-brackish lacustrine setting, thickness changes across the Shanchiao fault suggest subsidence due to prehistoric earthquakes. Nevertheless, all of the boreholes suggest that the deposition setting changed to alluvial deposition in the mid-Holocene (ca. 7-8 kyr B.P.). This thus hampered our understanding toward of possible paleoearthquakes since this time.

\subsection{Evidence and timing of prehistoric earthquakes}

Using the conceptual normal fault model, subsidence events are easily identified by abrupt changes in stratigraphic thickness. Stratigraphic relations in boreholes SCF05 and SCF06 show that the older subsidence event occurred at about 11,100 cal.yr B.P. and involved a displacement of about $2 \mathrm{~m}$ (Fig. 7). The younger subsidence event, involving a displacement of about $3 \mathrm{~m}$, occurred at about 9000 to 9300 cal. yr B.P. The total net offset over the past 14,000 years is about $10 \mathrm{~m}$. If we restore the strata by removing the cumulative displacement of $5 \mathrm{~m}$, a residual net offset of $5 \mathrm{~m}$ remains. The $5 \mathrm{~m}$ of offset could accommodate at least two additional rapid subsidence events. Even

Table 4

Estimations of prehistoric earthquakes

\begin{tabular}{llll}
\hline $\begin{array}{l}\text { Maximum } \\
\text { displacement }(\mathrm{m})\end{array}$ & $\begin{array}{l}\text { Moment } \\
\text { magnitude }\end{array}$ & $\begin{array}{l}\text { Average } \\
\text { displacement }(\mathrm{m})\end{array}$ & $\begin{array}{l}\text { Surface } \\
\text { rupture length }(\mathrm{m})\end{array}$ \\
\hline 2.3 & 6.9 & 1.3 & 33 \\
2.7 & 6.9 & 1.6 & 36 \\
3.3 & 7 & 2 & 40 \\
3.7 & 7 & 2.3 & 43 \\
4.5 & 7.1 & 2.8 & 48 \\
\hline
\end{tabular}

$\mathrm{MD}$, maximum displacement (m); M, moment magnitude; $\mathrm{AD}$, average displacement (m); SRL, surface rupture length $(\mathrm{km})$. The empirical relationships between these fault parameters followed Wells and Coppersmith (1994). 
though the stratigraphic records from boreholes do not provide direct evidence for other subsidence events, additional prehistoric subsidence cannot be eliminated.

Stratigraphic relations between boreholes SCF01 and SCF02, located along the central part of the fault, exhibits a similar thickening pattern (Fig. 7). The net offset increased abruptly at 9100-9300 cal.yr B.P., suggesting about $4.5 \mathrm{~m}$ of subsidence. Stratigraphic relations from these two boreholes also record a subsidence event of approximately $3.7 \mathrm{~m}$ at $8400-8600 \mathrm{cal}$. yr B.P. The two prehistoric subsidence events cannot fully account for the total net offset during the past 10,000 years. About $8 \mathrm{~m}$ of net offset remain after 7-8 $\mathrm{m}$ of displacement is removed from the two proposed events, suggesting the likelihood of additional subsidence events. The contact between the Jingmei gravel and the Sungshan Formation did not represent a contemporaneous surface in borings SCF01 and SCF02. The amount of net offset at the bottom of the Sungshan Formation ranges from 16.8 to $24.7 \mathrm{~m}$, thus the timing of possible subsidence events before 9100 cal. yr B.P. is uncertain.

Strata from boreholes SCF15, SCF16, SCF14, and SCF17, located at the southwestern corner of the Taipei Basin, did not show substantial offset in the past 10,000 years. Along the Shanchiao fault, strata younger than 8000 cal. yr B.P. were deposited in an alluvial setting and do not allow detailed stratigraphic correlation between boreholes due to the local depositional environment, lack of good stratigraphic markers, and age controls.

\subsection{Estimates for prehistoric subsidence from empirical relationships}

Estimates of prehistoric earthquake magnitude commonly rely on comparisons between inferred fault displacement and empirical regressions of historic fault length, coseismic offset, and magnitude (Wells and Coppersmith, 1994). Because patterns of historic normal fault surface rupture are complex and discontinuous (Beanland et al., 1990; Crone and Machette, 1984), prehistoric magnitude estimates that rely on the length of a surface fault trace may underestimate earthquake magnitude. For example, surface rupture along the 1983 M7.3 Borah Peak, Idaho earthquake occurred on two segments of the Lost River fault, with substantial variations in the amount of offset along strike (Crone and Machette, 1984). Patterns of Holocene rupture along the Shanchiao fault could be similarly complex and we consider a $19-\mathrm{km}$ length of the Shanchiao fault to be the shortest likely rupture length during an earthquake.

From the displacements observed in the strata recovered from the boreholes, empirical relations between moment magnitude and historic fault rupture length help in estimating parameters of prehistoric earthquakes (Wells and Coppersmith, 1994). Assuming that our observed displacements represent the maximum displacements for each event, the likely magnitudes for prehistoric earthquakes provide model estimates for the surface rupture length. According to the regression equation established from historic earth-

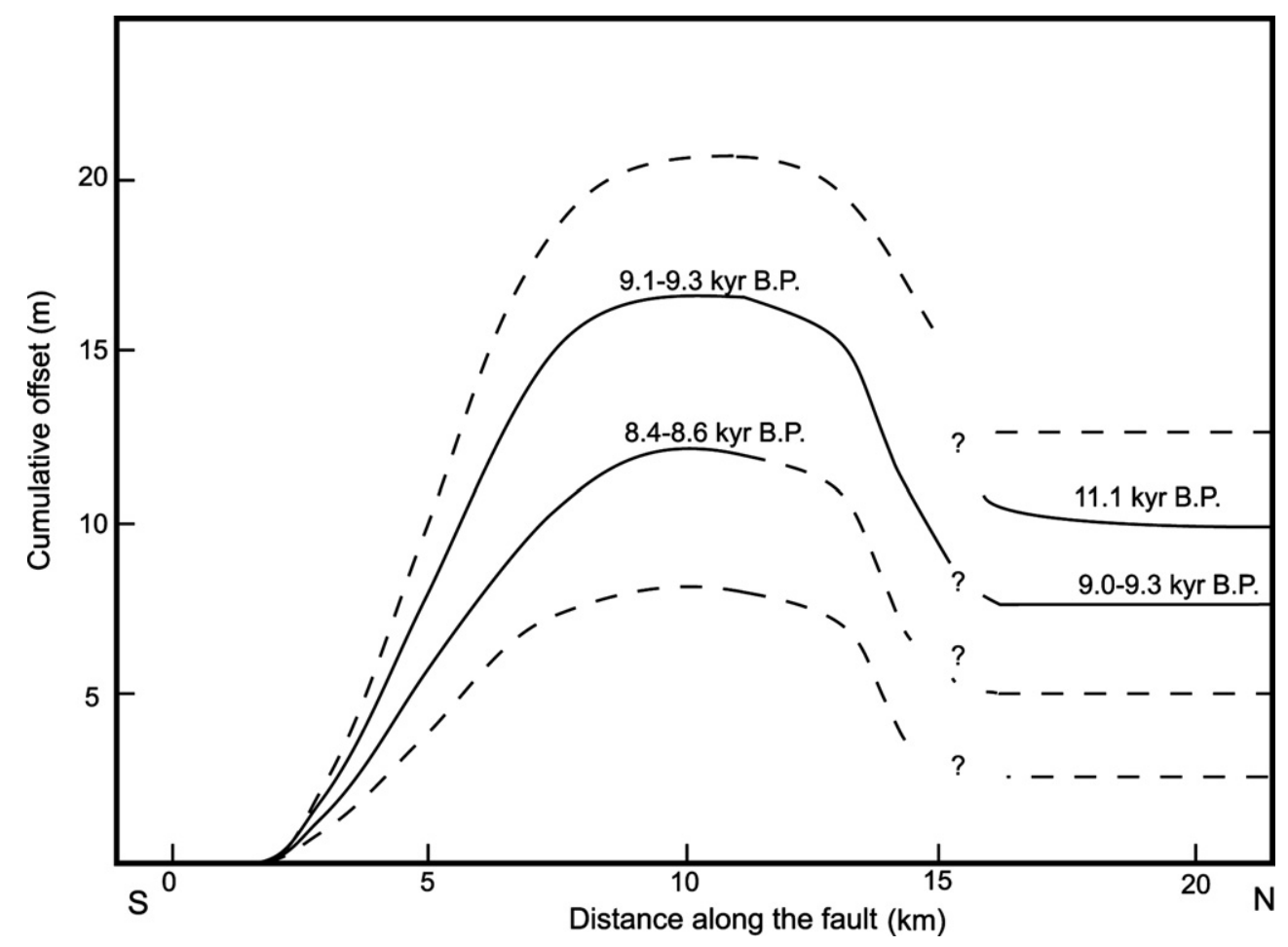

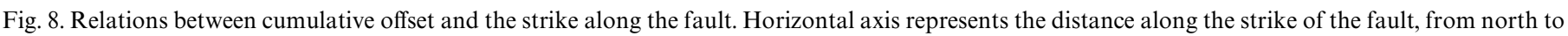

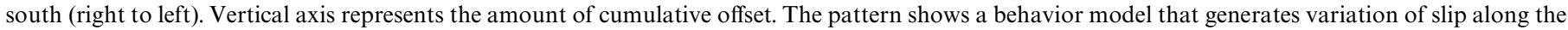
fault strike. Solid lines indicate observed data and dashed lines represent possible events that are not preserved in boreholes. 
quakes, fault displacements of over $2 \mathrm{~m}$ imply surface rupture lengths of tens of kilometers (Wells and Coppersmith, 1994); the continuous boring profiles in this study span only part of the surface rupture length during an earthquake on the Shanchiao fault. The displacements inferred from the correlation profiles along the Shanchiao fault range from 2.3 to $4.5 \mathrm{~m}$ and yield an estimated earthquake magnitude ranging from 6.9 to 7.1. These magnitudes imply a surface rupture length from 33 to $48 \mathrm{~km}$ (Table 4). Alternatively, using $3.3 \mathrm{~m}$ as the average observed displacement along the fault, empirical scaling relations indicate a magnitude of about 7.0. This implies a surface rupture length of about $40 \mathrm{~km}$. Such long ruptures are substantially longer than the known length of the Shanchiao fault.

\subsection{Fault behavior and inferred slip rates}

Fault behavior models assume that co-seismic displacement on a fault varies with time either at a single location or along the trace of the fault. Fault behavior models also assume that the elapsed time between earthquakes is related to the amount of strain released in each event. If fault segments, asperities, barriers, and areas of localized strain accumulation exist, they should reveal themselves in the pattern of surface deformation (Scholz, 1990).

As discussed previously, strata from the northern boreholes SCF05 and SCF06 recorded two subsidence events with 3.3 and $2.3 \mathrm{~m}$ of displacement at about 9000 9300 cal. yr B.P. and 11,100 cal. yr B.P., respectively. In the central part of the fault, boreholes SCF01 and SCF02 recorded $3.7 \mathrm{~m}$ of subsidence at $8400-8600 \mathrm{cal}$. yr B.P. and $4.5 \mathrm{~m}$ at $9100-9300 \mathrm{cal}$. yr B.P. If we assume that subsidence occurring between 9000 and 9300 cal. yr B.P. in the north is the same as the $9100-9300$ cal. yr B.P. event in the central area, a fault model that generates the same amount of slip in same-length segments with persistent slip patches along the fault might be appropriate (Fig. 8). Here, the displacement per event is constant along strike, but the long-term slip rate may differ considerably at any given location along the fault. The boreholes located in the southern area of the Shanchiao fault do not display offset since the mid Holocene. The cumulative displacement of the fault decreases from the central to the northern part of Shanchiao fault, suggesting that more moderate earthquakes might be expected along the northern area.

Although the amount of slip per event on the Shanchiao fault is difficult to determine, a long-term vertical separation rate can be estimated by using the top of Tertiary basement as a horizontal stratagraphic marker and the elapsed time from the onset of sedimentation in the basin to the present. Assuming the top of the Linkou Tableland in the footwall of the fault correlates with the top of the Tertiary basement beneath the basin (Fig. 2) and the initial deposition of Quaternary strata in the Taipei Basin immediately followed subsidence of the basin, the total offset for the past 400,000 years is approxi- mately $900 \mathrm{~m}$. This yields a long-term rate of $\sim 2.25 \mathrm{~mm} /$ yr. The geologic rate is consistent with geodetically determined rates of $0.3-2.1 \mathrm{~mm} / \mathrm{yr}$ (Yu et al., 1999a). Due to the absence of fault exposure and lack of historic seismicity, the Shanchiao fault has been placed in the second category of active faults that have ruptured within 100,000 years B.P (Lin et al., 2000).
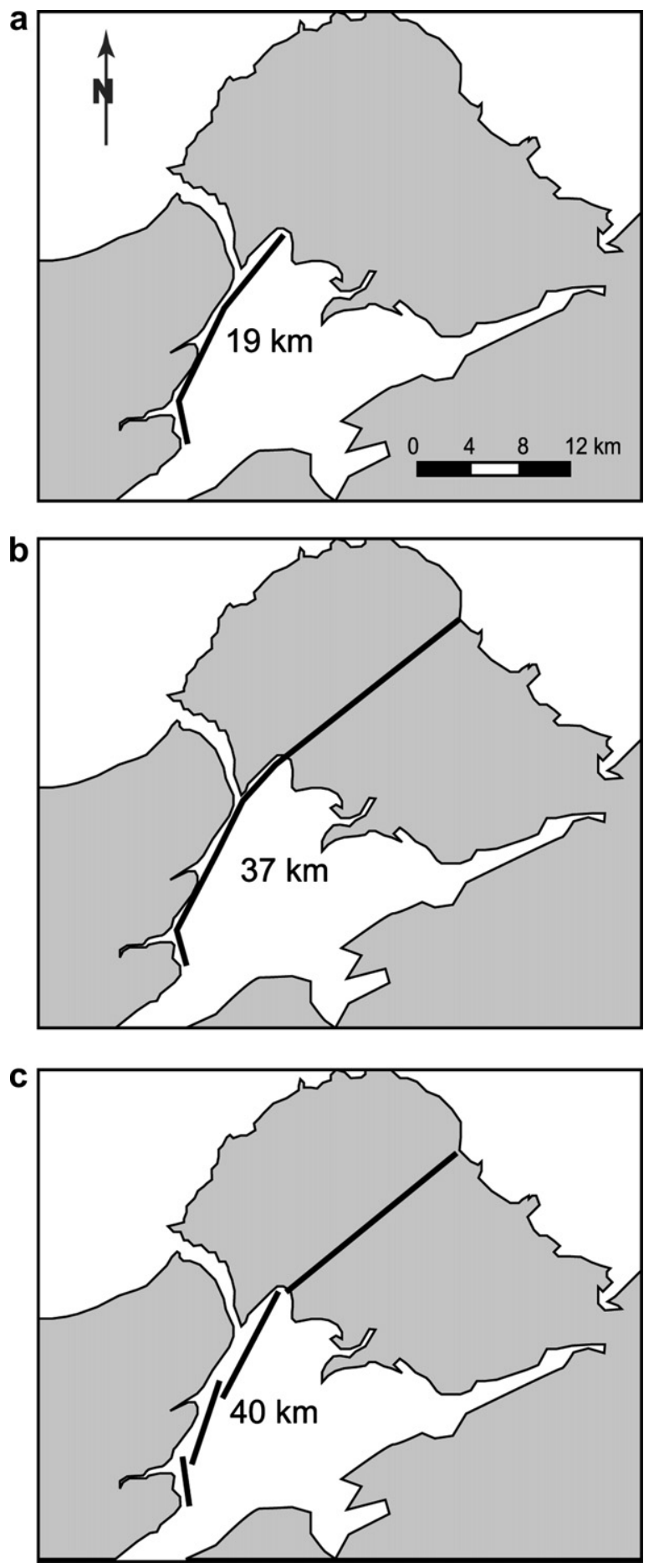

Fig. 9. Proposed fault strike length of the Shanchiao fault. (a) The fault is $19 \mathrm{~km}$ long and is restricted to Taipei Basin. (b) The fault is $37 \mathrm{~km}$ long and is marked by a prominent lineation. (c) The fault is $40 \mathrm{~km}$ long and extends offshore to the northeast. 
The Holocene separation rates for the Shanchiao fault appear lower than the long-term rate. The inferred separation rate along the northern part of the Shanchiao fault is approximately $0.69 \mathrm{~mm} / \mathrm{yr}$ for the past 15,000 years. Along the central part of the fault, the inferred separation rate is approximately $1.8 \mathrm{~mm} / \mathrm{yr}$ for the past 10,000 years. This variation in separation rate between the northern and central areas may reflect local variations in strain accumulation and previous slip patterns.

\subsection{The extent of the Shanchiao fault}

The prominent scarp between the Linkou Tableland and the Taipei Basin marks the surface trace of the Shanchiao fault (Fig. 1). Extending the fault trace to the north, the fault cuts the western flank of the Tatun Volcano area and its exact surface trace becomes ambiguous (Fig. 1).

Three rupture scenarios are presented with different fault surface lengths (Fig. 9). Using regressions from Wells and Coppersmith (1994), the surface rupture length of the Shanchiao fault is estimated to range from 33 to $48 \mathrm{~km}$. This suggests that the fault trace may extend further north to the coast. Although linear features along the western flank of the Tatun Volcano were previously reported as the trace of the inactive reverse Chinshan fault (Lin, 1957), these subtle topographic features may represent the northern extension of the Shanchiao fault (Fig. 1). In addition, a historic earthquake in 1867 that produced surface subsidence and a local tsunami near the town of Chinshan (Fig. 1) might represent an earthquake on the northern extension of the Shanchiao fault.

\section{Conclusions}

Data from eight continuous boreholes along the Shanchiao fault reveal evidence for abrupt thickening patterns that imply several prehistoric rapid subsidence events. Correlation profiles of estuarine to lacustrine deposits from each borehole pair across the Shanchiao fault document prehistoric earthquakes on the northern and central sections of the fault between $8.4,9.3$, and $11 \mathrm{ka}$. The earthquakes recorded by deposition along the northern profile occurred about 9-9.3 ka and produced $2-3 \mathrm{~m}$ of displacement. An earlier earthquake occurred at about $11 \mathrm{ka}$ produced similar displacements. The earthquakes recorded along the central profile occurred at $8.4-8.6 \mathrm{ka}$ and produced $4-5 \mathrm{~m}$ of displacement. Also, an earlier subsidence event is recorded between 9.1 and $9.3 \mathrm{ka}$ with similar displacements. Correlation profiles from the southern section of Shanchiao fault did not show any apparent displacement in the estuarine-lacustrine deposits across the Holocene.

The variation of displacement along strike of the fault may reflect the segmentation of the Shanchiao fault. Based on displacements of about $2-4 \mathrm{~m}$ per earthquake estimated from stratigraphic relations and empirical regressions, the Shanchiao fault could yield a $M \sim 7$ earthquake, corresponding with a surface rupture of $>33 \mathrm{~km}$. This rate is lower than the geodetically determined interseismic rate of strain accu- mulation. Although elsewhere in Taiwan, $M>7$ earthquakes have occurred, our results indicate that large earthquakes have occurred close to Taipei City. Large surface displacements have the potential for disrupting lifeline systems and producing substantial damage to modern buildings.

\section{Acknowledgements}

We thank Drs. Lisa Ely and Marie Ferland for their valuable comments and discussion. We also thank Drs. Brian Atwater, Harvey Kelsey, Kenneth Ridgway, and Karl Muller for their insightful editorial comments. The ICP-MASS and Stable Isotope Laboratories, Department of Geosciences, National Taiwan University supported the grain size and total carbon content analyses. This study was supported by National Science Funding and Sino-American Program, National Science Council. The Central Geological Survey, Taiwan, helped defray the costs of radiocarbon analyses and provided access to the borehole cores.

\section{References}

Beanland, S., Blick, G.H., Darby, D.J., 1990. Normal faulting in a back arc basin: geological and geodetic characteristics of the 1987 Edgecumbe earthquake, New Zealand. Journal of Geophysical Research 95 (B4), 4693-4707.

Bos, A.G., Spakman, W., 2003. Surface deformation and tectonic setting of Taiwan inferred from a GPS velocity field. Journal of Geophysical Research 108 (B10), 2458-2465.

Chen, F.-Y., Liew, P.-M., 1990. Palynological study of the Sungshan Formation, Taipei Basin. Proceedings of the Geological Society of China $33,21-37$.

Chen, M.-T., Wang, C.-H., Huang, C.-Y., Wang, P., Wang, L., Sarnthein, M., 1999. A late Quaternary planktonic foraminifer faunal record of rapid climatic changes from the South China Sea. Marine Geology 156 (1-4), 85-108.

Crone, A.J., Machette, M.N., 1984. Surface faulting accompanying the Borah Peak earthquake, central Idaho. Geology 12 (11), 664-667.

Grossman, M.J., Brown, A.G., Kadomura, H., 2001. Large floods and climatic change during the Holocene on the Ara River, central Japan. Geomorphology 39 (1-2), 21-37.

Ho, C.S., 1986. An introduction to the geology of Taiwan: explanatory text of the geologic map of Taiwan. Central Geological Survey, MOEA, Taipei. pp. 163.

Liew, P.-M., Huang, C.-Y., Tseng, M.-H., 1997. Preliminary study on the late Quaternary climatic environment of the Taipei Basin and its possible relation to basin sediments. Journal of the Geological Society of China 40, 17-30.

Lin, C.-C., 1957. Geomorphology of Taiwan. Taiwan Archive Commission, $424 \mathrm{pp}$.

Lin, C.-W., Chang, H.-C., Lu, S.-T., Shih, T.-S., Huang, W.-J. (Eds.), 2000. An introduction to the active faults of Taiwan. Special publication of Central Geological Survey, 13. Central Geological Survey, Taipei, Taiwan, $122 \mathrm{pp}$.

McCalpin, J.P., Nishenko, S.P., 1996. Holocene paleoseismicity, temporal clustering, and probabilities of future large $(M>7)$ earthquakes on the Wasatch fault zone, Utah. Journal of Geophysical Research 101 (B3), 6233-6253.

Scholz, C.H., 1990. The mechanics of earthquakes and faulting. Cambridge University Press, NY. 439 pp.

Schwartz, D.P., Coppersmith, K.J., 1984. Fault behavior and characteristic earthquakes; examples from the Wasatch and San Andreas fault zones. Journal of Geophysical Research 89 (B7), 5681-5698. 
Stuiver, M., Polach, H.A., 1977. Discussion: reporting of ${ }^{14} \mathrm{C}$ data. Radiocarbon 19 (3), 355-363.

Stuiver, M., and Reimer, P., 2002. CALIB 4.3: Seattle, Washington, The UW Quaternary Isotope Laboratory.

Suppe, J., 1984. Kinematics of arc-continent collision, flipping of subduction, and back-arc spreading near Taiwan. Memoir of the Geological Society of China 6, 21-33.

Teng, L.S., 1990. Geotectonic evolution of late Cenozoic arc-continent collision in Taiwan. Tectonophysics 183 (1-4), 57-76.

Teng, L.S., Lee, C.T., Peng, C.-H., Chen, W.-F., Chu, C.-J., 2001. Origin and geological evolution of the Taipei Basin, northern Taiwan. Western Pacific Earth Sciences 1 (2), 115-142.

Teng, L.S., Yuan, P.B., Chen, P.Y., Peng, C.H., Lai, T.C., Fei, L.Y., Liu, H.C., 1999. Lithostratigraphy of Taipei Basin deposits. In: C.S. Chen (Ed.), Special Issue for the Subsurface Geology and Engineering Environment of Taipai Basin. Special publication no.11. Central Geological Survey, Taipei, pp. 41-66.
Wen, K.L., Peng, H.Y., 1998. Site effect analysis in the Taipei Basin: results from TSMIP network data. TAO 9 (4), 691-704.

Wei, K., Chen, Y.-G., Lu, T.-K., 1998. Sedimentary history of the Taipei Basin with constraints from thermoluminescence dates. Journal of the Geological Society of China 41 (1), 109-125.

Wells, D.L., Coppersmith, K.J., 1994. New empirical relationships among magnitude, rupture length, rupture area, and surface displacement. Bulletin of the Seismological Society of America 84 (4), 974-1002.

Yu, S.-B., Chen, H.-Y., Kuo, L.-C., 1997. Velocity field of GPS stations in the Taiwan area. Tectonophysics 274, 41-59.

Yu, S.-B., Chen, H.-Y., Kuo, L.-C., Hou, C.-S., Lee, J.-F., 1999a. A study on the fault activities of the Taipei Basin. In: Chen, C.-H. (Ed.), Special Issue for the Subsurface Geology and Engineering Environment of the Taipei Basin. Central Geological Survey, MOEA, Taipei, pp. 227-251.

Yu, S.-B., Kuo, L.-C., Punongbayan, R.S., Ramos, E.G., 1999b. GPS observation of crustal deformation in the Taiwan-Luzon region. Geophysical Research Letter 26, 923-926. 